УДК 658:327:061.1€С(477)

DOI: https://doi.org/10.32851/2708-0366/2020.3.9

Копитова I.B.

кандидат економічних наук, доцент,

Поліський національний університет ORCID: http://orcid.org/0000-0003-3800-3285

Федоренко В.О. кандидат фрілософьських наук, профресор МКА, Житомирський інститут Міжрегіональної академії управління персоналом

Kopytova Iryna Polissya National University

Fedorenko Valeriy Zhytomyr Institute of Interregional Academy of Personnel Management

\title{
МАРКЕТИНГОВІ КОМУНІКАЦІЇ В КОНТЕКСТІ \\ ГЛОБАЛЬНИХ ТРАНСФОРМАЦІЙ ТА «ЄВРОПЕЇЗАЦІЇ» СУЧАСНОЇ УКРАЇНИ
}

\section{MARKETING COMMUNICATIONS IN THE CONTEXT OF GLOBAL TRANSFORMATIONS AND "EUROPEANIZATION" OF MODERN UKRAINE}

У статті запропонований аналіз проблеми маркетингових комунікаиій в умовах глобальних трансформачій та «європеїзаиї» сучасної Украӥни. Філософсько-економічне розуміння сутності, змісту, механізму, особливостей процесу глобалізації, який означає входження всього людства в єдину систему соиіально-культурних, економічних, політичних, духовних та інших зв 'язків і відносин, дає можливість розглядати його як одну з детермінант ефективності маркетингових комунікацій. Маркетингові комунікаиії розглядаються як один з основних елементів комплексу маркетингу підприємства, як певні форми і способи інформування иільової аудиторії про його продукт, щуо функиіонально залежить від суб 'єктивних та об' 'ктивних умов, у яких здійснюється і якими детермінована маркетингова діяльність. Особливе місие серед них належить процесу євроатлантичної інтеграиії та співпраці з НАТО. Автори підкреслюють залежність маркетингових комунікацій 
як мінімум від двох діалектично взаємопов'язаних проиесів: по-перще, ие запровадження кращзого європейського досвіду у вітчизняну практику маркетингових комунікацій з урахуванням украӥнської дійсності, позитивних та негативних наслідків глобальних трансформацій, а по-друге - безумовне виконання європейських норм, стандартів НАТО украӥнськими підприємствами.

Ключові слова: глобалізм, європеїзачія, маркетинг, маркетингові комунікачїі, інтернет-реклама, зв'язки з громадськістю, інтегровані маркетингові комунікацї.

В статье предложен анализ проблемы маркетинговых коммуникаций в условиях глобальных трансформаций и «европеизации» современной Украиньл. Философско-экономическое понимание сущзности, содержания, механизма, особенностей процесса глобализации, который означает вхождение человечества в единую систему социально-культурных, экономических, политических, духовных и иных связей и отношений дает возможность рассматривать его как одну из детерминант эффективности маркетинговых коммуникаций. Маркетинговые коммуникации рассматриваются как один из основных элементов комплекса маркетинга предприятия, как определенные формы и способы информирования целевой аудитории о его продукте, функционально зависящем от субъективных и объективных условий, в которых осуществляется и которыми детерминирована маркетинговая деятельность. Особое место среди них принадлежит проиессу евроатлантической интеграции и сотрудничества с НАТО. Авторы подчеркивают зависимость маркетинговых коммуникаций как минимум от двух диалектически взаимосвязанных процессов: во-первых, это введение лучшего европейского опыта в отечественную практику маркетинговых коммуникаций с учетом украинской действительности, положительных и отрицательных последствий глобальных трансформаций, а во-вторых - безусловное выполнение европейских норм, стандартов НАТО украинскими предприятиями.

Ключевые слова: глобализм, европеизация, маркетинг, маркетинговые коммуникации, интернет-реклама, связи с общественностью, интегрированнье маркетинговые коммуникации.

The article offers an analysis of the problem of marketing communications in the conditions of global transformations and "Europeanization" of modern Ukraine. Philosophical and economic understanding of the essence, content, mechanism, features of the globalization process, which means the entry of all mankind into a single system of socio-cultural, economic, political, spiritual and other ties and relations gives an opportunity to consider it as one of the determinants of the effectiveness of marketing communications. Marketing communications are considered as one of the main elements of the marketing complex of the enterprise, as certain forms and ways of informing the target audience about the product of the enterprise, which functionally depends on subjective and objective conditions in which marketing activities are carried out and determined. A special place among them belongs to the process of Euro-Atlantic integration and cooperation with NATO. The authors emphasize the dependence of marketing communications in at least two dialectically interconnected processes: firstly, it is the introduction of the best European experience in the domestic practice of marketing communications practice, taking into account the Ukrainian reality, positive and negative consequences of global transformations, and secondly, unconditional performance of European norms, NATO standards by Ukrainian enterprises. In the new historical conditions the essence, the content of the form of marketing communications changes, their types and tools are improved. Particular attention in the conditions of global transformations is paid to the improvement of advertising and its type as Internet-advertising, which today has become one of the most popular and most effective. It is emphasized that the full and high-quality implementation of functions of marketing communications in modern conditions is impossible without the effective functioning of such types of marketing communications as public relations and integrated marketing communications (IMC). Its direct connection with marketing lies in the fact that the mechanisms of public relations is the engine of the process of promoting the product on the market, ensuring the success of the enterprise. And the idea of IMC is based on the thesis that all elements of the marketing complex can be considered as a means of communication and all of them should be used in a concerted manner in the communication process. The concept of IMC allows you to combine all forms of communication and helps to increase sales.

Key words: globalism, Europeanization, marketing, marketing communications, Internet advertising, public relations, integrated marketing communications. 
Постановка проблеми. Маркетингові комунікації є одним з основних елементів комплексу маркетингу підприємства як певні форми і способи інформування цільової аудиторії про його продукт. Вони функціонально залежні від суб'єктивних і об'єктивних умов, у яких здійснюються і якими детерміновані. Особливе місце серед них належить процесам глобальних трансформацій та «європеїзації» сучасної України, тому вони потребують системного аналізу та врахування в маркетинговій діяльності.

Аналіз останніх досліджень і публікацій. Зазначена проблема перебуває у центрі уваги багатьох вітчизняних та зарубіжних науковців: Г. Алмонда, Г. Аппеля, Л. Брауна, С. Блєка, Р. Колісніченка, К. Клюка, Н. Бутенка, Ю. Баличева, О. Романенка, С. Холленсена та інших. У їхніх працях розглядаються актуальні проблеми глобалістики та іiї вплив на діяльність людини, на соціально-економічні процеси у сучасній Україні, на процес «європеїзації» відповідно до вимог європейських норм і стандартів, що суттєво впливає на сутність, зміст, особливості маркетингових комунікацій. Разом із тим у межах цих досліджень є чимало невивчених і суперечливих питань, у тому числі пов'язаних із глобальними трансформаціями та «європеїзацією» сучасної України, на що вказують і самі дослідники.

Формулювання цілей статті. Мета статті - проаналізувати особливості й характер впливу сучасних глобальних трансформацій та процесу «європеїзації» сучасної України на сутність, зміст, форми, види маркетингових комунікацій відповідно до європейських норм та стандартів НАТО.

Виклад основного матеріалу. Соціально-економічні процеси в сучасній Україні, а відповідно - маркетингові комунікації, пов'язані з низкою детермінантів, які потрібно враховувати в управлінській діяльності. Насамперед обрання євроатлантичного вектору розвитку та співпраці з НАТО в умовах сучасних глобальних трансформацій, які неоднозначно впливають на всі сфери суспільного життя в Україні, а особливо на економічну.

Природно, що економіка була іє першоосновою процесів глобалізації. Саме в економічній сфері суспільного життя зароджуються соціальні наслідки. Саме внаслідок змін у глобальній економіці в останню чверть XX ст. реальний валовий світовий продукт, який визначає сукупний обсяг економічної діяльності всіх людей у всіх країнах, більш ніж подвоївся. Разом із тим реальним чинником є диспропорції у розвитку країн світу, в яких відбиваються зміни і реформування всієї системи світових відносин.

На наш погляд, методологічно можна виділити два типи реформ, що відбуваються у сучасному світі. Реформи націлені на перегляд завоювань модерну в міжнародних відносинах, охорону наявних прав та інтересів своїх громадян і подальше нарощування споживання в межах існуючої політичної організації суспільства та зі зміцненням становища розвинутих країн у світоекономіці. Другий тип реформ пов'язаний зі зміною форм власності, руйнуванням традиційного устрою життя, цивілізаційних морально-етичних основ, необхідністю докорінної демократизації політичної влади. Результатами реформ і першого, і другого типу є все більший відрив передових країн, які реально увійшли в інтелектуальну еру, від решти країн, у тому числі й країн із перехідною економікою.

Вчені занепокоєні тим, що без певних обмежень в управлінні процесом глобалізації маргіналізація бідних країн здійснюється ще більш швидкими темпами. Так, американський дослідник Л. Браун розробив концепцію «сталого розвитку», яка передбачає зміни характеру світової економіки, трансформацію системи міжнародних відносин, запровадження спільного світового керівництва глобальними соціальними й економічними процесами [1, с. 44].

По-друге, в умовах сучасної глобалізації в інтересах країн, що розвиваються, для вирівнювання глобального економічного, політичного, культурного розвитку існує 
потреба під час реалізації модернізаційних цілей врахування національних традицій, особливостей культури, свідомості, менталітету місцевого населення, його бачення глобальних проблем та шляхів нейтралізації світових небезпек.

У країнах світу сучасна глобалізація посилює тенденцію до різкої поляризації суспільства. На частку однієї п'ятої найзаможнішого та наближеного до найзаможнішого населення планети припадає 94\% світового багатства. Один відсоток найбагатшого населення планети володіє майже половиною (48\%) всього багатства світу. Згідно з експертними підрахунками, на частку найбагатших 80 осіб припадає стільки ж багатства, скільки і на частку 3,5 млрд найбіднішого населення планети [2, с. 310]. Означена нерівність грубо порушує принципи справедливого розподілу матеріальних благ, створює істотні перепони на шляху до економічного розвитку. Безумовно, такий вплив глобальних трансформацій позначається на процесі євроатлантичної інтеграції, співпраці з НАТО сучасної України. Суттєво мінімізує ефективність цього процесу і військовий конфлікт на Сході України.

Саме внаслідок конфлікту український бізнес, а переважно середній, скоріше 3 політичних міркувань, ніж з економічних, втратив ринки збуту своєї продукції у ближньому зарубіжжі, не отримавши євроатлантичні. Такий стан справ підтверджує, що євроатлантична інтеграція, співпраця з НАТО - досить складне соціальне явище, яке $\epsilon$ предметом дослідження багатьох наук: філософії, політології, економіки, менеджменту, соціології, права тощо.

Філософсько-економічне розуміння сутності, змісту цього процесу розкриває залежність його ефективності від двох основних чинників: стану об'єктивних і суб'єктивних умов та їх урахування; оптимальності функціонування основних структурних елементів процесу євроінтеграції та їх оптимізованості. Одним із ключових об'єктивних чинників детермінації цього процесу $є$, по-перше, стан глобалістичної свідомості європейського та українського суспільства в їхньому діалектичному взаємозв'язку, по-друге, «європеїзація» відповідно до вимог європейських норм і стандартів НАТО [3, с. 15]. Саме успішне виконання європейських норм і стандартів дає права на членство в ЄС. У науковій літературі така практика отримала назву «європеїзація». Найбільш всеохоплююче і водночас лаконічне визначення цього феномену дають Ф. Шімельфеннінг та У. Зедельмаєр [4, с. 12].

Наведені дані дають всі підстави стверджувати про залежність маркетингових комунікацій від глобальних трансформацій та «європеїзації» сучасної України як мінімум у двох діалектично взаємопов'язаних процесах: по-перше, це запровадження кращого європейського досвіду у вітчизняну практику маркетингових комунікацій 3 урахуванням реалій української дійсності та позитивних і негативних наслідків глобальних трансформацій; по-друге - безумовне виконання європейських норм і стандартів НАТО українськими підприємствами.

Маркетингові комунікації як певні форми і способи інформування цільової аудиторії про продукт підприємства є одним з основних елементів його системи маркетингу. У розпорядженні фахівців з маркетингу перебувають спеціальні інструменти, що сприяють максимальному збільшенню впливу власної комунікаційної діяльності. Виділяють основні інструменти маркетингових комунікацій, такі як реклама, зв'язки з громадськістю, стимулювання збуту, прямий маркетинг, а також синтетичні, такі як спонсорство, виставки, ярмарки, упаковка, місце продажу, мережа Internet, фірмовий стиль, мерчандайзинг, брендинг [5, с. 266].

Усі маркетингові комунікації орієнтовані на вирішення певних завдань, які, в свою чергу, повинні відповідати цілям комунікаційної програми. Зазвичай у число цих цілей входить поширення певної інформації, створення у покупців обізнаності про торгову марку, підвищення культури ринку, формування позитивного іміджу компанії або іiі торгової марки. Кінцева мета будь-якої стратегії маркетингових комунікацій полягає 
в тому, щоб допомогти підприємству продати його продукт і збільшити прибутковість власного бізнесу.

Комплекс маркетингових комунікацій із просування товару на ринок формує систему ФОПСТИЗ, яка включає в себе заходи з формування попиту. Система ФОП (формування попиту) орієнтована на виконання трьох основних завдань: просування на ринок товарів ринкової новизни; забезпечення початкових продажів; завоювання певної частки ринку. Важливою формою маркетингових комунікацій, за допомогою якого формується попит на продукцію, є реклама, яка має свій інструментарій. Особливої уваги в умовах глобальних трансформацій заслуговує такий вид реклами, як Internet-реклама, головна перевага якої - можливість швидкого інформування про товар цільової аудиторії, оминаючи географічні кордони. Вже зараз можна з упевненістю стверджувати, що у неї є дві великих переваги - можливість миттєво і гнучко реагувати на запити користувача і так само оперативно відстежувати результативність рекламних дій.

Отже, для забезпечення стабільної прибутковості сучасних підприємств відтепер недостатньо просто пропонувати найкращий товар за найприйнятнішою ціною. Сучасні умови вимагають від підприємств постійно створювати попит на товар. Саме на це і спрямована їхня рекламна діяльність. В усьому світі видатки на рекламу підприємств постійно зростають, тому зростає необхідність в обізнаності щодо переваг та недоліків різних видів реклами, про новітні рекламні технології, а також про ефективність їхнього впливу на поведінку покупців. Вирішення цих завдань залежить від ефективності функціонування такого виду маркетингових комунікацій, як зв'язки 3 громадськістю.

У сучасному глобалізованому світі свою залежність від суспільства усвідомлює кожна організація, що формує іiі потребу у побудові гармонійних зв'язків із громадськістю, яка, з одного боку, є носієм національної свідомості, а з іншого - глобалістичної. Їхній безпосередній зв'язок із маркетингом полягає в тому, що саме механізми зв'язків із громадськістю є двигуном процесу просування продукту на ринок, забезпечуючи успіх підприємства, його імідж та репутацію в умовах жорсткої конкуренції. Зв'язки з громадськістю (від англ. public relations або PR) як форма маркетингової комунікації формує сприятливу суспільну думку для підприємства i впливає на нього різними методами (статті в пресі, інтерв'ю, робота 3 аудиторією в social media, iнфошум) для покращення репутації. Роль зв'язків із громадськістю полягає в тому, щоб максимально ефективно впливати на суспільство, застосовуючи різні методи, для формування репутації та впізнаваності бренду, будувати системи комунікацій для взаємодії з громадськістю.

Класичне визначення PR дано C. Блеком: «PR - це мистецтво і наука досягнення гармонії із зовнішнім оточенням за допомогою взаєморозуміння, заснованого на правді і повній інформованості" [6, с. 17]. Воно досі вважається найкращим, оскільки містить у собі найвизначальніші ознаки цієї форми маркетингової комунікації. Зв'язки 3 громадськістю - управління комунікаціями між організацією і громадськістю 3 метою створення й підтримки доброзичливих відносин та взаєморозуміння.

Узагальнивши різноманітні визначення сутності зв'язків із громадськістю, можна запропонувати синтезований підхід, розуміючи це соціальне явище як особливу функцію управління, покликану: встановлювати та підтримувати взаємозв'язки, взаєморозуміння та співпрацю між організацією та громадськістю; вирішувати суперечливі питання між владою та окремими групами громадськості; вивчати громадську думку та розробляти відповідні форми реакції на неї; визначати та підкреслювати відповідальність керівництва перед громадськістю; допомагати керівництву ефективно змінюватися відповідно до потреб часу; передбачати тенденції суспільного розвитку, 3 метою попередження тих, які носять негативний характер [7, с. 345]. 
Водночас зв'язки з громадськістю не можуть виступати: а) перешкодою між правдивою інформацією та громадськістю; б) системою пропаганди, спрямованої на те, щоб що-небудь нав'язати комусь без урахування вимог правдивості, етичних норм, громадських інтересів; в) системою дій, спрямованих тільки на сприяння розширенню реалізації товарів і послуг, незважаючи на те, що зв'язки з громадськістю мають важливе значення для формування продажів і вдосконалення маркетингової діяльності; г) звичайною роботою із 3MI, незважаючи не те, що вона і виступає важливою складовою частиною багатьох програм зв'язків із громадськістю [8].

Непередбачуване ринкове середовище вимагає від своїх учасників встановлення результативних контактів із різними цільовими аудиторіями: клієнтами, партнерами, інвесторами, представниками владних структур і ділових кіл. Тому сучасний маркетинг неможливий без компетентності у сфері зв'язків з громадськістю як функції управління, 3 гнучким використанням соціально-психологічних методів управління людськими ресурсами для створення ділової атмосфери, злагоди та взаєморозуміння. Ефективне використання зв'язків із громадськістю створює привабливі умови для функціонування таких основних інструментів маркетингових комунікацій, як стимулювання збуту.

Стимулювання збуту (СТИЗ) як форма маркетингових комунікацій являє собою систему короткострокових спонукальних заходів і прийомів, спрямованих на заохочення покупки або продажу товару, що приймають форму додаткових пільг, зручностей, економії тощо. Іншими словами, покупці або інші цільові аудиторії, на яких спрямовані стимулюючі заходи, отримують щось безкоштовно, або за меншу ціну, або 3 великими зручностями. Характерною особливістю цих заходів $є$ те, що вони безпосередньо не пов'язані зі споживчими властивостями продукту. У цьому принципова відмінність стимулювання збуту від традиційної реклами. Тому передбачається, що основні споживчі властивості вже відомі [9, с. 34].

Під впливом глобалістичних трансформацій у практичній діяльності стали використовуватися різні підходи до маркетингових комунікацій. Заслуговує на увагу підхід, що отримав назву «інтегровані маркетингові комунікації» (IMК), який почав активно запроваджуватися на початку 90-х рр. в США, а потім і в Європі. В основі ідеї ІМК лежить теза про те, що всі елементи комплексу маркетингу можна розглядати як комунікаційні засоби і всі вони повинні узгоджено використовуватися в комунікаційному процесі. Концепція ІМК дозволяє поєднати всі форми комунікацій і сприяє збільшенню продажів. Як показує сучасна практика, завоювання нового клієнта обходиться підприємству в 6-10 разів дорожче, ніж утримання постійного. ІМК сприяють формуванню лояльності споживачів, їх утриманню, адже основний прибуток підприємства приносять саме $25 \%$ лояльних споживачів [10, с. 188].

Інтегровані маркетингові комунікації - це скоординоване поєднання маркетингових заходів, яке є специфічним для об'єкта просування, що застосовується для досягнення комунікаційної, економічної та соціальної ефективності маркетингової діяльності фірми, яка працює у взаємодії реального і віртуального середовищ [11, с. 58]. Метою ІМК є створення синергії, тобто досягнення такого узгодженого використання декількох інструментів маркетингових комунікацій, яке здатне принести більший ефект, ніж за їх окремого застосування. Синергетичний ефект виникає за системного поєднання елементів маркетингового повідомлення, що передається різними засобами комунікаційного впливу. Перевагами інтегрованого маркетингу є: творча цілісність, узгодженість повідомлень, неупереджені маркетингові рекомендації, ефективніше використання всіх засобів інформації, вища маркетингова точність, операційна ефективність, економія витрат, постійний висококласний сервіс, спрощені робочі відносини, вища відповідальність агентства [12].

IMК - достатньо новий інструмент в практиці маркетингу, багато його аспектів $\epsilon$ ще недостатньо вивченими. У зв'язку з цим концепція IMК перебуває в стані активного вивчення як практиків, так і теоретиків маркетингу. 
Висновки. Таким чином, маркетингові комунікації мають важливе значення і $\epsilon$ одними з найбільш значущих 3-поміж питань підвищення конкурентоспроможності та сталого розвитку підприємства. Використання маркетингових комунікацій в умовах глобальних трансформацій та «європеїзації» сучасної України дозволяє підприємству постійно бути присутнім в інформаційному просторі й отримувати зворотний зв'язок від цільової аудиторії. У сучасній інформаційній економіці особливого значення набуває інтеграція комунікаційних інструментів у реальному та віртуальному середовищі. Теоретики і практики маркетингу дедалі більше схиляються до думки, що кожен елемент складного процесу просування може бути інтегрований. Процес створення ІМК має індивідуальні особливості для кожного конкретного підприємства, що є перспективним напрямом подальших наукових досліджень.

\section{Список використаних джерел:}

1. Колісніченко Р.М. Глобалістична свідомість людства: політологічний аналіз: монографія. Київ : ДП «Вид. дім «Персонал», 2017. 422 с.

2. Колісніченко Р.М. Глобалістична свідомість в умовах диспропорцій глобального економічного розвитку. Гілея: науковий вісник. 2016. Вип. 109. С. 305-312. URL: http://nbuv.gov.ua/ UJRN/gileya_2016_109_81 (дата звернення: 14.10.2020).

3. Копитова І.В., Федоренко В.О. Вплив глобалістичної свідомості на процес Європеїзації сучасної України. Інтелект XXI. 2019. № 2. С. 14-17.

4. Шіммельфеннінг Ф., Зедельмаєр У. Свропеїзація Центральної та Східної Європи. Київ : Юніверс, 2010. 288 с.

5. Кузик О.В. Ефективність впливу маркетингових комунікацій на поведінку споживачів в Україні. Науковий вісник НЛТУ Украӥни. 2013. Вип. 23.12. С. 265-271. URL: http://nbuv.gov.ua/ UJRN/nvnltu_2013_23 (дата звернення: 12.10.2020).

6. Блэк С. Паблик рилейшнз. Что это такое? Москва : Модино Пресс, 1999. 239 с.

7. Харлоу Р. Паблик Рилейшнз. Москва: Эксмо, 2005. 367 с.

8. Записки маркетолога. PR в системе маркетинга. URL: http://www.marketch.ru/notes_on_ marketing/marketing_tactics/pr_marketing/(дата звернення: 12.10.2020).

9. Корінев В.Л., Зав'ялова М.В. Особливості стимулювання збуту продукції вітчизняних підприємств на ринку. Вісник Запорізького національного університету. Економічні науки. 2017. № 1. C. 32-39. URL: http://nbuv.gov.ua/UJRN/Vznu_eco_2017_1_6(дата звернення: 14.10.2020).

10. Романенко О.О. Інтегровані маркетингові комунікації: сутність, характеристика та особливості формування. Збірник наукових пращь Національного університету державної податкової служби України. 2013. № 1. C. 187-196. URL: http://nbuv.gov.ua/UJRN/znpnudps_2013_1_19 (дата звернення: 12.10.2020).

11. Литовченко И.Л., Шкурупская И.А. Интегрированные маркетинговые коммуникации предприятий на рынке гелиоэнергетического оборудования : монография. Киев : Наукова думка, 2015. 212 с.

12. Головкіна Н.В., Шутовський Д.О. Інтегровані маркетингові комунікації організації: головні переваги впровадження. Вісник Київського національного університету технологій та дизайну. 2013. № 4. С. 116-123. URL: http://nbuv.gov.ua/UJRN/Vknutd_2013_4_23 (дата звернення: 12.10 .2020$)$.

\section{References:}

1. Kolisnichenko R.M. (2017) Ghlobalistychna svidomistj ljudstva: politologhichnyj analiz [Globalist consciousness of mankind: political analysis]. Kyiv: DP «Vyd. dim «Personal». (in Ukrainian)

2. Kolisnichenko R.M. (2016) Ghlobalistychna svidomistj v umovakh dysproporcij ghlobaljnogho ekonomichnogho rozvytku [Globalist consciousness in the conditions of disproportions of global economic development]. Ghileja: naukovyj visnyk, vol. 109, pp. 305-312. Available at: http://nbuv.gov.ua/UJRN/gileya_2016_109_81 (accessed 14 October 2020).

3. Kopytova I.V., Fedorenko V.O. (2019) Vplyv ghlobalistychnoji svidomosti na proces Jevropejizaciji suchasnoji Ukrajiny [The influence of globalist consciousness on the process of Europeanization of modern Ukraine]. Intelekt XXI, no. 2, pp. 14-17. 
4. Shimmeljfenningh F., Zedeljmajer U. (2010) Jevropejizacija Centraljnoji ta Skhidnoji Jevropy [Europeanization of Central and Eastern Europe]. Kyiv: Junivers. (in Ukrainian)

5. Kuzyk O.V. (2013) Efektyvnistj vplyvu marketynghovykh komunikacij na povedinku spozhyvachiv v Ukrajini [The effectiveness of the impact of marketing communications on consumer behavior in Ukraine]. Naukovyj visnyk NLTU Ukrajiny, vol. 23.12, pp. 265-271. Available at: http://nbuv.gov.ua/UJRN/nvnltu_2013_23 (accessed 12 October 2020).

6. Blek S. (1999) Pablik rileyshnz. Chto eto takoe? [Public relations. What is it?]. Moscow: Modino Press. (in Russian)

7. Kharlou R. (2005) Pablik Rileyshnz [Public Relations]. Moscow: Eksmo. (in Russian)

8. Zapiski marketologa. PR v sisteme marketinga [Marketer's notes. PR in the marketing system]. Available at: http://www.marketch.ru/notes_on_marketing/marketing_tactics/pr_marketing (accessed 12 October 2020).

9. Korinev V.L., Zav'jalova M.V. Osoblyvosti stymuljuvannja zbutu produkciji vitchyznjanykh pidpryjemstv na rynku [Features of sales promotion of domestic enterprises on the market]. Visnyk Zaporizjkogho nacionaljnogho universytetu. Ekonomichni nauky, no. 1, pp. 32-39. Available at: http://nbuv.gov.ua/UJRN/Vznu_eco_2017_1_6 (accessed 14 October 2020).

10. Romanenko O.O. (2013) Integhrovani marketynghovi komunikaciji: sutnistj, kharakterystyka ta osoblyvosti formuvannja [Integrated marketing communications: essence, characteristics and features of formation]. Zbirnyk naukovykh pracj Nacionaljnogho universytetu derzhavnoji podatkovoji sluzhby Ukrajiny, no. 1, pp. 187-196. Available at: http://nbuv.gov.ua/UJRN/znpnudps_2013_1_19 (accessed 12 October 2020).

11. Litovchenko I.L., Shkurupskaya I.A. (2015) Integrirovannye marketingovye kommunikatsii predpriyatiy na rynke gelioenergeticheskogo oborudovaniya [Integrated marketing communications of enterprises in the solar energy equipment market]. Kyiv: Naukova dumka. (in Ukrainian)

12. Gholovkina N.V., Shutovsjkyj D.O. (2013) Integhrovani marketynghovi komunikaciji orghanizaciji: gholovni perevaghy vprovadzhennja [Integrated marketing communications of the organization: the main advantages of implementation]. Visnyk Kyjivsjkogho nacionaljnogho universytetu tekhnologhij ta dyzajnu, no. 4, pp. 116-123. Available at: http://nbuv.gov.ua/UJRN/Vknutd_2013_4_23 (accessed 12 October 2020). 